Maciej Ptaszyński

Instytut Historyczny

Uniwersytet Warszawski

\title{
O buntowniczą nowożytność. Uwagi na marginesie najnowszych prac Luise Schorn-Schütte ${ }^{1}$
}

Epoka nowożytna sama ochrzciła się „nową”, odróżniając się, piórem Christopha Cellariusa, od wieków średnich i starożytności ${ }^{2}$. Tę novitas wyznaczały przemiany kulturowe, społeczne, religijne i polityczne, które nie zawsze przez współczesnych oceniane były pozytywnie. Wraz ze zmianami mentalnymi przełomu XIX i XX w. nowożytność stała się epoką historyczną poprzedzającą i przygotowującą nadejście nowoczesności. Wówczas narodziły się schematy, które - w duchu Maxa Webera i Ernsta Troelscha definiowały nowożytność w kategoriach racjonalizacji, sekularyzacji i oddzielenia państwa od Kościoła oraz polityki od religii ${ }^{3}$. Historiografię owładnęła

${ }^{1}$ Artykuł jest zarazem recenzją publikacji: L. Schorn-Schütte, Gottes Wort und Menschenherrschaft. Politisch-Theologische Sprachen im Europa der Frühen Neuzeit, München 2015, ss. 302; eadem, Perspectum. Ausgewählte Aufs̈̈tze zur Frühen Neuzeit und Historiographiegeschichte anlässlich ihres 65. Geburtstages, hrsg. von A. Kürbis, H. Kürbis, M. Friedrich, München 2015 (Historische Zeitschrift, Beihefte. Neue Folge, Bd. 61), ss. 419. Badania sfinansowane ze środków Narodowego Centrum Nauki przyznanych na podstawie decyzji numer DEC$-2013 / 09 / \mathrm{B} / \mathrm{HS} 3 / 00604$.

2 „In primis Ecclesiae reformatio meretur, ut novam historiam, distinctam ab illa quae medii aevi fuit, ex saeculo decimo sexto, aut prope illius initia, auspicemur", Ch. Cellarius, Historia Nova, hoc est XVI et XVII saeculorum qua eiusdem auctoris historiae, antiqua et mediiaevi, ad nostra tempora continenti ordine proferuntur, cum notis erpetuis et indice rerum, Halle 1696, s. 3.

${ }^{3}$ Zob. krytyczne uwagi: B. Stollberg-Rilinger, Die Frühe Neuzeit - eine Epoche der Formalisierung, w: Die Frühe Neuzeit. Revisionen einer Epoche, hrsg. von A. Höfele, 
fascynacja państwem, jego funkcjonowaniem i biurokratycznymi strukturami - dzieckiem nowożytności i potężnym hegemonem wieku XX. W tej epoce stworzono klisze historiozoficzne, które w duchu „hermeneutyki podejrzeń" (Zygmunta Freuda, Karola Marksa czy Fryderyka Nietzschego) przypisywały aktorom na dziejowej scenie niewyartykułowane przesłanki działań albo tymże działaniom - niezamierzone skutki ${ }^{4}$. Jak ostatnio wykazywał Arndt Brendecke, za tymi historiograficznymi wyjaśnieniami stał często ugruntowany przez koncepcje Hegla schemat, nakazujący szukać przyczyn i antecedencji historycznych zjawisk w niewidzialnych procesach i przemianach, czyli „niewidzialnej istotowości” („unsichtbare Wesentlichkeit") 5 .

Luise Schorn-Schütte, specjalizująca się w historii społecznej i konfesyjnej epoki nowożytnej oraz w dziejach historiografii początku XX w., broni w swoich pracach tezy, że nowożytność nie była tylko początkiem i „inkubatorem" nowoczesności. W ostatnio wydanej monografii Gottes Wort und Menschenherrschaft badaczka stawia pytania o specyfikę „nowych czasów”, wywodząc ją ze wspólnoty systemów wiedzy i wartości, znajdującej wyraz w języku, którym teologowie i prawnicy opisywali relacje między religią a polityką. Historiograficzne i metodologiczne podstawy stawianych przez Autorkę tez naświetla tom Perspectum, obejmujący trzynaście artykułów powstałych w latach 1976-2004. Opublikowany w 2015 r. wybór, stanowiący urodzinowy upominek, opatrzono bibliografią dotychczasowych prac badaczki oraz przedmową Markusa Friedricha; nakreślił on charakterystykę Schorn-Schütte jako badacza epoki nowożytnej.

Perspectum dokumentuje drogę naukową historyka rozpoczynającego karierę od studiów z pogranicza dziejów prawa, historii społecznej oraz regionalistyki. Niezwykle ważnym akcentem był doktorat poświęcony postaci wybitnego niemieckiego historyka, pioniera historii kultury („Kulturgeschichte”) Karla Gottharda Lamprechta (1865-1915), napisany

J.-D. Müller, W. Österreicher, Berlin-Boston-Göttingen 2013, s. 3-27; C. Zwierlein, Frühe Neuzeit, Multiple Modernities, Globale Sattelzeit, w: Frühe Neue Zeiten. Zeitwissen zwischen Reformation und Revolution, hrsg. von A. Landwehr, Bielefeld 2012, s. 389-406; J. Duindam, Early Modern Europe. Beyond the Structures of Modernization and National Historiography, „European History Quarterly”, 40, 2010, s. 606-623. Ostatnio w bardzo eseistycznej formie poruszono w: B. S. Gregory, The Unintended Reformation. How a Religious Revolution Secularized Society, Cambridge 2012.

${ }^{4}$ Zob. B. Steiner, Nebenfolgen in der Geschichte. Eine historische Soziologie reflexiver Modernisierung, Berlin-München-Boston 2015; por. też C. Zwierlein, Return to Premodern Times? - Contemporary Security Studies, the Early Modern Holy Roman Empire, and Coping with Achronies, „German Studies Review”, 38, 2015, s. 373-392.

5 A. Brendecke, Eine tiefe, frühe, neue Zeit. Anmerkungen zur 'bidden agenda' der Frühneuzeitforschung, w: Die Frühe Neuzeit, s. 29-45. 
pod kierunkiem Gerharda Oestreicha i obroniony w 1981 r. w Osnabrück ${ }^{6}$. Wedle ustaleń Schorn-Schütte, Lamprecht, postulujący umieszczenie dziejów regionalnych w uniwersalnym kontekście oraz łączenie historii społecznej i kulturowej, odcisnął silne piętno na niemieckiej, francuskiej i amerykańskiej historiografii XX stulecia ${ }^{7}$. Warto podkreślić, że Schorn-Schütte zwróciła także uwagę na wpływ Lamprechta na polską historiografię, wśród jego uczniów w Lipsku znalazł się bowiem Wacław Sobieski, a prace lipskiego profesora budzily zainteresowanie Ludwika Finkla ${ }^{8}$. Już w tym historiograficznym studium o Lamprechcie odnaleźć można tematy z późniejszych publikacji Schorn-Schütte, poświęconych zarówno nowym ujęciom i modelom teoretycznym, odnoszącym się do epoki nowożytnej, jak i wybranym zagadnieniom analitycznym.

Metody przyjęte przez Autorkę w studium Gottes Wort und Menschenherrschaft zawdzięczają wiele anglosaskiej tradycji szkoły historyków idei z Cambridge (Cambridge School, New History of Ideas), którzy, za Johnem R. Pocockiem i Quentinem Skinnerem, programowo porzucili analizy wielkich pism klasycznej historii idei, włączając do rozważań teksty mniej przełomowe, za to bardziej masowe i reprezentatywne dla stylu myślenia epok dawnych. Za tym szerszym uwzględnieniem dzieł niepierwszorzędnych krył się także postulat kontekstualizacji tez badaczy idei, zbliżający historię społeczną i - wywodzące się z politologii oraz filozofii - nurty historii idei. Jak zauważa Schorn-Schütte, celem tych działań było nie tyle poszukiwanie antecedencji współczesności, ile zrozumienie odmienności, opis zmian oraz uchwycenie procesualności rozwoju historycznego ${ }^{9}$.

Autorka Gottes Wort und Menschenherrschaft zajęła się również językiem politycznym. Na przykładzie debat toczonych w Rzeszy w latach 1530 -1650 (rozdz. 2, s. 31-130), zestawianych z dyskusjami w Anglii, Francji, Niderlandach, Austrii i Rzeczypospolitej (rozdz. 3, s. 131-184), przedstawiła nowożytne problemy źródeł i granic władzy świeckiej. Rozważania rozpoczynają się od utartej tezy historiograficznej przypisywanej przede

${ }^{6}$ L. Schorn-Schütte, Karl Lamprecht. Kulturgeschichtsschreibung zwischen Wissenschaft und Politik, Göttingen 1984.

7 Zob. eadem, Territorialgeschichte, Provinzialgeschichte - Landesgeschichte, Regionalgeschichte. Ein Beitrag zur Wissenschaftsgeschichte der Landesgeschichte, w: Perspectum, s. 111-143; eadem, Karl Lamprecht. Wegbereiter der historischen Sozialwissenschaft, w: ibidem, s. 144-190; eadem, Nachwirkungen der Lamprechtschen Geschichtsschreibung. Rezeption im Ausland und in der deutschen Geschichtswissenschaft und Soziologie, w: ibidem, s. 191-212.

8 Eadem, Karl Lamprecht. Kulturgeschichtsschreibung, s. 331-335; zob. także pracę doktorską powstałą pod kierunkiem L. Schorn-Schütte: M. Ogrin, Ernst Bernheim (1850-1942). Historiker und Wissenschaftspolitiker im Kaiserreich und in der Weimarer Republik, Stuttgart 2012, s. 333-338.

${ }^{9}$ L. Schorn-Schütte, Gottes Wort, s. 20; szerzej na ten temat: eadem, Historische Politikforschung. Eine Einführung, München 2006, s. 53-58. 
wszystkim Ernstowi Troeltschowi i zarzucającej luteranizmowi polityczną bierność i konformizm, a przeciwstawiającej go niepokornemu, buntowniczemu i demokratycznemu kalwinizmowi ${ }^{10}$. Tezę tę Schorn-Schütte obala lub relatywizuje, wskazując długą tradycję oporu wobec władzy świeckiej $\mathrm{w}$ łonie luteranizmu.

Za punkt wyjścia studiów Schorn-Schütte uznać trzeba moment konstytuowania się politycznego obozu protestantów i dyskusje towarzyszące protestacji na sejmie w Spirze (1529) oraz powstaniu Związku Szmalkaldzkiego (1530-1532). Opinię wpływowego Lazarusa Spenglera (1479-1534), który uważał przemoc za niedopuszczalną i zalecał poddanie się cesarzowi, Autorka przeciwstawia pismu Jana Bugenhagena, sporządzonemu w 1530 r., pod nieobecność w Wittenberdze Marcina Lutra i Filipa Melanchtona ${ }^{11}$. Fragment listu św. Pawła do Rzymian nakazujący bezwzględne posłuszeństwo wobec władzy (Rz 13) Bugenhagen podważył, powołując się na wersety z Pierwszej Księgi Samuela: „Nie pójdę z tobą, gdyż odrzuciłeś słowo Pana i dlatego odrzucił cię Pan. Nie będziesz już królem nad Izraelem" (1 Sam 15, 26-28) ${ }^{12}$. Ponieważ cała władza pochodzi od Boga, na władcę nałożono szczególne zobowiązania w kwestiach wiary i kultu. W sytuacji, gdy władca lekceważy te obowiązki, jego panowanie traci również legitymizację. W następnych dwóch dekadach tę argumentację zaakceptował nie tylko Filip Melanchton, lecz także wielu wiodących teologów luterańskich (jak Andreas Osiander) oraz mniej znanych duchownych (jak Geog von Waltersdorff) czy prawników (jak Johannes von der Wyck, Erastus Albert czy Basilius Monner) ${ }^{13}$.

Dyskusja nad prawem do oporu wobec władzy świeckiej nabrała intensywności w drugiej połowie lat czterdziestych XVI w., gdy doszło do militarnego starcia, w wyniku którego cesarz pokonał protestantów i podyktował w Augsburgu warunki pokoju. Interim augsburskie przywracało katolicką naukę o usprawiedliwieniu, siedem sakramentów, mszę i kult świętych, a także sądownictwo biskupie i liczne katolickie ceremonie. Z dorobku reformacji zachowano jedynie komunię pod dwiema postaciami i uznano zawarte już

10 Zob. szerzej: eadem, Ernst Troeltschs „Soziallehren” und die gegenwärtige Frühneuzeitforschung. Zur Diskussion um die Bedeutung von Luthertum und Calvinismus für die Entstehung der modernen Welt, w: eadem, Perspectum, s. 213-231.

11 Eadem, Gottes Wort, s. 35-40.

12 Opinia Bugenhagena przedrukowana w: Das Widerstandsrecht als Problem der deutschen Protestanten, hrsg. von H. Scheible, Gütersloh 1982, s. 25-29; zob. analizę w: D. Böttcher, Ungehorsam Oder Widerstand? Zum Fortleben des mittelalterlichen Widerstandrechtes in der Reformationszeit (1529-1530), Berlin 1991, s. 23-25.

13 Por.: L. Schorn-Schütte, Gottes Wort, s. 52-53; eadem, Justifying Force in Early Modern Doctrines on Self-Defence and Resistance, w: The European Wars of Religion. An Interdisciplinary Reassessment of Sources, Interpretations, and Myths, ed. by W. Palaver, H. Rudolph, D. Regensburger, Farnham 2016, s. 139-164. 
małżeństwa księży ${ }^{14}$. Dla duchownych luterańskich Interim stanowiło największy kryzys od czasu reformacji: po śmierci Marcina Lutra zabrakło autorytetu, który mógłby poprowadzić teologów.

Ocena znaczenia Interim augsburskiego stanowi wyzwanie dla historiografii. Publikacja dokumentu w 1548 r. wywołała bardzo różnorodne reakcje, co sprawia, że dla każdego z terytoriów Rzeszy oraz licznych miast należałoby napisać odrębną historię zmagań. Do 1971 r., gdy Horst Rabe ogłosił pierwsze nowoczesne i analityczne studium poświęcone recepcji Interim w Rzeszy, kwestie te należały do najbardziej zaniedbanych obszarów niemieckiej historiii ${ }^{15}$. Wedle Schorn-Schütte to zaniedbanie było wynikiem dwóch tendencji historiograficznych: koncentracji badań nad reformacją na osobie zmarłego w 1546 r. Lutra, a niemieckojęzycznego dziejopisarstwa - na Rzeszy rozumianej w kategoriach państwowo-narodowej jedności ${ }^{16}$. Do nadrobienia tych zaległości w ostatnich latach przyczyniły się przede wszystkim studia inicjowane przez Autorkę recenzowanych prac oraz Irene Dingel ${ }^{17}$.

W pracy Gottes Wort und Menschenherrschaft Autorka nie rekonstruuje złożonego procesu wprowadzenia nowych regulacji na terytoriach Rzeszy, lecz zwraca uwagę na opór wielu teologów wywołany przez Interim augsburskie. Justus Menius, Georg Major, Justus Jonas czy Friedrich Myconius na kartach swych dzieł dyskutowali nie tylko problemy teologiczne, lecz także zagadnienia polityczne. Najsłynniejsze i najdonioślejsze wypowiedzi przeciw Interim i cesarzowi sformułowali luterańscy duchowni przebywający w Magdeburgu, który odmówił przyjęcia Interim i przez kilkanaście miesięcy na przełomie 1549 i 1550 r. opierał się wojskom koalicji cesarskiej ${ }^{18}$. Podobnie bezkompromisowo luterańscy duchowni zachowywali się w licznych lokalnych starciach drugiej połowy XVI i na początku wieku XVII. W świetle ustaleń Schorn-Schütte język teologiczno-polityczny kształtował się w sporach

14 Das Augsburger Interim: nach den Reichstagsakten deutsch und lateinisch, hrsg. von J. Mehlhausen, Neukirchen 1970.

15 Por.: H. Rabe, Reichsbund und Interim. Die Verfassung- und Religionspolitik Karls V. und der Reichstag von Augsburg 1547/1548, Köln 1971; idem, Entstehung des Augsburger Interims 1547/48, „Archiv für Reformationsgeschichte”, 94, 2003, s. 6-104.

16 Por. L. Schorn-Schütte, Das Interim (1548/1550) im europäischen Kontext. Eine wissenschaftliche Einleitung, w: Das Interim. Herrschaftskrise und Glaubenskonflikt, hrsg. von L. Schorn-Schütte, Gütersloh 2005, s. 15-44, tu s. 18-33.

17 Oprócz tomu Das Interim należy zwrócić uwagę na prace doktorskie powstałe pod kierunkiem L. Schorn-Schütte: A. Moritz, Interim und Apokalypse. Die religiöse Vereinheitlichungsversuche Karls V. im Spiegel der magdeburgischen Publizistik 1548-1551/52, Tübingen 2009; R. Berwinkel, Weltliche Macht und geistlicher Anspruch. Die Hansestadt Stralsund im Konflikt um das Augsburger Interim, Berlin 2008; zob. też Reaktionen auf das Augsburger Interim, hrsg. von I. Dingel, Göttingen 2010.

18 Por. L. Schorn-Schütte, Gottes Wort, s. 59-63. 
o granice władzy świeckiej z przełomu lat dwudziestych i trzydziestych XVI w., a najpełniejszy wyraz znalazł w sporze o Interim. Ukute wówczas argumenty i sposoby dowodzenia były wykorzystywane w większości kontrowersji XVI i XVII w. ponad granicami konfesyjnymi i politycznymi.

We wszystkich debatach zazwyczaj wykorzystywano tezy, które uważano za wzajemnie się wspierające, a nie wykluczające czy konkurujące. Obok biblijnych zobowiązań (1 Sam 15, 26) opisywano strukturę Rzeszy, uprawniającą niższy magistrat („magistratus inferior”) do obrony poddanych, nawet przed cesarzem. Ponadto włączono do dyskusji klasyczną figurę tyrana jako antywładcy, targającego się na swoich poddanych. Wreszcie, m.in. za sprawą Melanchtona, powołano się na „prawo natury” („lex naturae”) i prawo rzymskie zezwalające na samoobronę w chwili zagrożenia („vim vi repellere licet”).

Schorn-Schütte szczególną uwagę zwróciła na figurę trzech stanów tworzących społeczne uniwersum, która po raz pierwszy pojawiła się w myśli europejskiej około XI w. dzięki Adalbertowi z Laon i Gerhardowi z Cambrai, i stopniowo zawładnęła światem średniowiecznej wyobraźni - zarówno w obrębie tradycji arystotelesowskiej, jak i platońskiej ${ }^{19}$. W myśl dominującej w XV w. nauki o trzech stanach społeczeństwo dzieliło się na laboratores, oratores i bellatores, do których zadań należało - odpowiednio - dostarczanie żywności, modlitwa i obrona chrześcijańskiego świata. Teologowie czasu przełomu reformacyjnego, niechętni scholastycznemu dziedzictwu, początkowo nie odwoływali się explicite do tej tradycji. Dla myśli Marcina Lutra i rodzącej się reformacji znacznie ważniejsze było rozróżnienie dwóch królestw („zwei Reiche”) czy dwóch rodzajów rządów („zwei Regimente”), zakładające rozdzielenie państwa Bożego i państwa ziemskiego. Zgodnie z tą koncepcją Kościoła i państwa nie przedstawiano jako oponentów ani też bytów sobie podporządkowanych, lecz działających od siebie niezależnie $^{20}$. Stopniowo w myśli luterańskiej pojawiały się jednak coraz częstsze nawiązania do trójpodziału społeczeństwa na Kościół, zwierzchność świecką i dom („Kirche, Obrigkeit und Haus”), czyli ecclesia, politica, oeconomia. Średniowieczna koncepcja zaczęła więc w połowie XVI w. ponownie zyskiwać popularność, ale z tą znaczącą różnicą, że nie było już mowy o walczących bellatores ani pracujących laboratores. Zamiast tego pojawił się stan

19 Zob.: eadem, Die Drei-Stände-Lehre im reformatorischen Umbruch, w: eadem, Perspectum, s. 251-280; eadem, „Drei-Stände-Lehre”, w: Das Luther-Lexikon, hrsg. von V. Leppin, G. Schneider-Ludorff, Regensburg 2014, s. 174-176; O. G. Oexle, Die funktionale Dreiteilung der 'Gesellschaft' bei Adalbert von Laon, „Frühmittelalterliche Studien”, 12, 1978, s. 1-54; G. Duby, Les trois ordres ou l'imaginaire du féodalisme, Paris 1979.

20 Por.: H. Bornkamm, Luthers Lehre von den zwei Reichen im Zusammenhang seiner Theologie, „Archiv für Reformationsgeschichte”, 49, 1958, s. 26-49; V. Mantey, Zwei Schwerte - Zwei Reiche. Martin Luthers Zwei-Reiche-Lehre vor ihrem spätmittelalterlichen Hintergrund, Tübingen 2005, s. 157-293, tu s. $245-259$. 
małżeński i zwierzchność świecka. Adaptacja ta wynikała zarazem ze stopniowego powrotu filozofii arystotelesowskiej na protestanckie uniwersytety, jak i z tradycji katechetycznej i refleksji nad czwartym przykazaniem ukazującym rodzinę (oeconomia) jako paradygmat władzy zwierzchniej. Koncepcja ta umożliwiała krytykę kleru zakonnego, umieszczającego się poza społeczeństwem, jak również wprowadzenie etyki do myśli luterańskiej. Taka wizja porządku społecznego stanowiła klamrę spinającą „dwa regimenty” Lutra, które w jego pierwotnym ujęciu były absolutnie rozdzielne. Szybko została przyjęta przez prawników i autorów popularnej literatury domowej („Hausväterliteratur”) ${ }^{21}$. W XVI-XVII w. koncepcja trzech stanów stała się ważnym argumentem $\mathrm{w}$ sporach toczonych przez duchownych $\mathrm{z}$ władzą świecką, gdy brali oni na siebie funkcję jej cenzorów. Funkcjonalna ekwiwalencja stanów pozwalała ich przedstawicielom wzajemnie oceniać i krytykować swoje działania. Jak przekonuje Schorn-Schütte, figura ta miała charakter ponadkonfesyjny.

$\mathrm{Na}$ tle europejskiej tradycji oporu Rzeczpospolita zajmuje miejsce wyjątkowe. Wedle Schorn-Schütte, w dyskusji na temat władzy świeckiej i jej granic w Polsce najważniejszą i niemal wyłączną rolę grały argumenty prawne ${ }^{22}$. Autorka podążając wiernie za ustaleniami historiografii, podkreśla legalizm cechujący kulturę polityczną szlachty polskiej i znaczenie kodyfikacji prawa do oporu w przywileju mielnickim z 1501 r., następnie w Artykułach Henrykowskich i ostatecznie ponownie przeformułowanych w okresie rokoszu Zebrzydowskiego (1606/1609). Warto w tym miejscu dodać, że bliższe spojrzenie na tradycję oporu wobec władzy ukazuje przede wszystkim jej średniowieczne korzenie oraz pozwala wyróżnić przynajmniej pięć nurtów konstytuowanych przez: (1) średniowieczne przywileje, (2) średniowieczne umowy międzynarodowe, (3) średniowieczny arystotelizm, (4) przywilej mielnicki, (5) nowożytną teorię polityczną. Poniżej zostaną one krótko scharakteryzowane ${ }^{23}$.

Tradycja prawa do oporu sięga w Polsce XII-XV w., z którego to okresu znanych jest ponad dziesięć dokumentów, gdzie posłużono się formułą wypowiedzenia posłuszeństwa jako gwarancją traktatu ${ }^{24}$. Zazwyczaj

21 Zob. pracę doktorską przygotowaną pod kierunkiem L. Schorn-Schütte: Ph. Hahn, Das Haus im Buch. Konzeption, Publikationsgeschichte und Leserschaft der „Oeconomia” Johann Colers, Epfendorf 2013.

22 L. Schorn-Schütte, Gottes Wort, s. 192, tab. 7.

23 Obszerne omówienie w: Diskussionen über Notwehr, Gegenwehr, Widerstandsrecht und das Gewissen. Normwandel in ständepolitischen Debatten im Europa des 16./17. Jahrhunderts, hrsg. von L. Schorn-Schütte (w druku); zob. też M. Ptaszyński, Zwischen Gemeinwohl und Staatsräson. Das Widerstandsrecht in den Ständedebatten der polnisch-litauischen Republik im 16. Jahrhundert, w: Frühneuzeitliche Reiche in Europa. Empires in Early Modern Europe, hrsg. von T. Gromelski, Ch. Preusse, A. Ross, D. Tricoire, Wiesbaden 2016, s. 67-87.

24 Zob.: A. Vetulani, Studia nad tekstami i znaczeniem statutu tęczyckiego z r. 1180, Lwów 1932; J. Adamus, Mniemana tęczycka ustawa sukcesyjna roku 1180, 
formuła ta miała warunkowy i dość zwyczajowy charakter: jeżeli władca złamie przyznane mocą dokumentu przywileje, poddani są zwolnieni z obowiązku posłuszeństwa. Do drugiej tradycji należały układy międzynarodowe, głównie pokoje zawierane z Zakonem Krzyżackim w XIV-XV w.; od pokoju kaliskiego (1343), przez pokój melneński (1422), po pokój brzeski (1435) umowy te zawierały klauzulę o wypowiedzeniu posłuszeństwa ${ }^{25}$. Fundamentem prawa do oporu w obu tradycjach była średniowieczna kategoria wierności (fides), na której opierał się system społeczny. Owa fides zobowiązywała poddanych do świadczenia auxilium et consilium, a władców - do obrony i gwarancji sprawiedliwości. Złamanie przez jedną ze stron powinności uwalniało drugą stronę od zobowiązań. Do tradycji średniowiecznych przywilejów dotyczących senatorów i możnych, którym przyznano prawo upominania władcy, należał wydany w 1501 r. przywilej mielnicki. Chociaż otwierał on nową epokę, to w wywodzie wykorzystano kluczową dla tradycji europejskiej kategorię tyrana, któremu przeciwstawiono universum regnum uwalniane od przysięgi („universum regnum sit liberum a iuramento et fide praestita") ${ }^{26}$. Mimo że przywilej praktycznie nie wszedł w życie, pamiętano o nim, gdy zbliżał się koniec panowania Zygmunta Augusta, a żywo dyskutowany dokument stanowił wzór dla formuły zamieszczonej w Artykułach Henrykowskich (1573) ${ }^{27}$. Na te Artykuły, zawierające zarówno

"Collectanea Theologica”, 17, 1936, s. 183-206; idem, Prawo oporu w Polsce średniowiecznej, „Sprawozdania z Czynności i Posiedzeń Łódzkiego Towarzystwa Naukowego", 14, 1959, s. 1-4; J. Wyrozumski, Od ius resistendi do ius de non praestanda oboedientia $w$ Polsce, w: Świat, Europa, mała ojczyzna. Studia ofiarowane profesorowi Stanistawowi Grodziskiemu w 80-lecie urodzin, red. M. Małecki, Bielsko-Biała 2009, s. 155-164.

25 Por.: E. Weise, Das Widerstandsrecht im Deutschordenslande Preussen und das mittelalterliche Europa, Göttingen 1955, s. 144-145; Codex Diplomaticus Regni Poloniae et Magni Ducatus Lituaniae, t. 4, wyd. M. Dogiel, Vilnae 1764, nr 65, s. 70; Dokumenty strony polsko-litewskiej pokoju metneńskiego z 1422 roku, wyd. P. Nowak, P. Pokora, Poznań 2004, s. 9; Die Staatsverträge des Deutschen Ordens in Preußen im 15. Jahrbundert, Bd. 1: 1398-1437, hrsg. von E. Weise, Königsberg 1939, nr 152-154, s. 150-164, tu s. 163; ibidem, nr 179-183, s. 195-213, tu s. 210; Acten der Ständetage Preussens unter der Herrschaft des Deutschen Ordens, Bd. 2, hrsg. von M. Toeppen, Leipzig 1880, nr 108, s. 170-176.

26 Volumina Constitutionum, t. 1, wyd. S. Grodziski, I. Dwornicka, W. Uruszczak, Warszawa 1996, s. 109-113; zob. też: L. Sobolewski, W. Uruszczak, Artykuty mielnickie z roku 1501, „Czasopismo Prawno-Historyczne”, 42, 1990, s. 31-61; F. Papée, Przywilej mielnicki, w: Ksiegga pamiątkowa ku czci Oswalda Balzera, t. 2, wyd. W. Abraham, P. Dąbrowski, L. Pieniński, Lwów 1926, s. 173-187.

${ }^{27} \mathrm{Na}$ temat artykułów zob.: D. Makiłła, Artykuty Henrykowskie (1573-1576). Geneza - obowiazywanie - stosowanie. Studium historyczno-prawne, Warszawa 2012; M. Ptaszyński, Die polnischen Wablkapitulationen des 16. Jahrhunderts und ihr Fortleben im 17. Jahrbundert, w: Wablkapitulationen in Europa, hrsg. von H. Duchhardt, Göttingen 2015, s. 59-72. 
gwarancję pokoju między rozróżnionymi w wierze, jak i formułę o wypowiedzeniu posłuszeństwa, powoływali się liczni polemiści w następnych stuleciach ${ }^{28}$.

Osobną tradycję stworzyli arystotelicy nauczający lub wykształceni na Uniwersytecie Krakowskim w XV stuleciu. W komentarzach do Polityki Arystotelesa, wykładach, traktatach i kazaniach rozwijano idee kontraktualizmu, dobra wspólnego i suwerenności prawa ${ }^{29}$. Na doktrynę prawa do oporu ujętą $\mathrm{w}$ arystotelesowskie kategorie uczeni powoływali się, pisząc dzieła uzasadniające wystąpienie stanów pruskich przeciw Zakonowi, a także - pomoc Polski i Litwy okazaną owym rebeliantom ${ }^{30}$. Na gruncie tej akademickiej tradycji, czerpiącej z debat koncyliarystycznych, narodziła się teoria polityczna XVI w., w ramach której element teorii oporu lub wypowiedzenia posłuszeństwa pojawia się na kartach pism Andrzeja Zaborowskiego, Frycza Modrzewskiego, Stanisława Orzechowskiego czy Andrzeja Wolana ${ }^{31}$.

Nie ulega wątpliwości, że zupełnie inny był stosunek tej teorii oporu do praktyki politycznej w Polsce, gdzie nigdy nie doszło do tak ostrego starcia na tle wyznaniowym jak w Rzeszy, Francji czy w Anglii. Należy jednak pamiętać, że formy i możliwości oporu obejmowały w nowożytności cały szereg zachowań: od krytyki i upominania władcy, po aktywną obronę własnych praw, gdzie rokosz czy nawet rebelia stanowiły rozwiązania skrajne i najradykalniejsze. Przykłady praktyki upominania władcy opisywano w dziełach

28 Zob. np.: J. Crell, O wolność sumienia, tł. I. Lichońska, red. Z. Ogonowski, Warszawa 1957; [D. Kałaj], Rozmowa Przyiacielska, ministra ewanielickiego z xiedzem katolickim, s.l. 1671 - tu: Dedykacja: „A jesliby się co stało temu naprzeciwko / abo in personam Regis, tedy ab omni fide \& obedientia Regibus debita solvuntur subditi, abo in personam alicujus, vel aliquarum ex Civibus Regni, tedy przeciwko takim / pacis \& securitatis Dissidentium violatoribus, obiecują Status Regni, sub fide honore \& conscientia związani pro se $\&$ succesoribus, powstać y znosić"; [D.E. Jabłoński], Jura et libertates Dissidentium in Religione Christiana, in Regno Poloniae et M.D. Lithuaniae ex Legibus Regni et aliis Monumentis authenticis excerpta, Berlin 1708. O sporach na temat konfederacji zob. M. Korolko, Klejnot swobodnego sumienia. Polemika wokót konfederacji warszawskiej w latach 1573-1658, Warszawa 1974.

29 Por. P. Czartoryski, Wczesna recepcja „Polityki” Arystotelesa na Uniwersytecie Krakowskim, Wrocław 1963.

30 K. Górski, Polski traktat polityczny w obronie Zwiąku Pruskiego, „Rocznik Olsztyński”, 7-8, 1968, s. 163, 171; idem, Pisma polskie w obronie Zwiazku Pruskiego a geneza Ztotej Wolności, „Roczniki Historyczne”, 18, 1949, s. 143-173; idem, Rządy wewnętrzne Kazimierza Jagiellończyka, w: M. Biskup, K. Górski, Kazimierz Jagiellończyk. Zbiór studiów o Polsce drugiej potowy XV wieku, Warszawa 1987, s. 82-128, tu s. 92-93; E. Weise, op. cit., s. 156, 163-165.

31 H. Litwin, W poszukiwaniu rodowodu demokracji szlacheckiej. Polska myśli polityczna w piśmiennictwie XV i początków XVI wieku, w: Między monarchą a demokracja. Studia z dziejów Polski XV-XVIII wieku, wyd. M. Żaryn, A. Sucheni-Grabowska, Warszawa 1994, s. 13-53. 
historycznych od czasów Wincentego Kadłubka i Jana Długosza ${ }^{32}$. Na kartach protokołów obrad sejmowych i sejmikowych od sejmu 1548 r. nie brakuje przykładów krytyki króla lub nawet gróźb wysuwanych pod adresem monarchy ${ }^{33}$. Przez całą epokę nowożytną bardzo żywa pozostawała tradycja rokoszu gliniańskiego (1379-1380), a następnie rokoszu lwowskiego (1537). Pierwszy był historyczną fikcją, drugi natomiast - manifestacją niezadowolenia szlachty i jej przywódców, którzy upomnieli króla i królową, żądając realizacji politycznych zobowiązań ${ }^{34}$. Plotki o przygotowywanym rokoszu krążyły po Koronie w 1549 r., gdy Zygmunt August nie ustąpił pod naciskiem stanów w sprawie małżeństwa z Barbarą Radziwiłłówną. W praktyce musiano sięgnąć po zobowiązania z Artykułów Henrykowskich w 1574 r. po ucieczce z Polski Henryka Walezego ${ }^{35}$. Jednak najostrzejszy spór między monarchą a stanami rozgorzał na początku panowania Zygmunta III Wazy. Do eskalacji konfliktów doszło na sejmie inkwizycyjnym (1592) oraz podczas rokoszu Zebrzydowskiego (1606-1607/1609) ${ }^{36}$. Rokosz sandomierski dostarczył już nie tylko okazji do upomnienia króla, lecz doprowadził do wypowiedzenia posłuszeństwa monarsze ${ }^{37}$. Podczas zjazdów, na których

32 Np. Magistri Vincentii dicti Kadtubek Cronica Polonorum, wyd. M. Plezia, Kraków, I, 13. Na temat tego fragmentu zob. S. Witkowski, Podstęp Leszka z kolcami u Kadtubka i jego źródto, w: Księga pamiątkowa ku czci Oswalda Balzera, t. 2, s. 677-690.

33 Por.: „Lecz iż Korona polska nie przyrodzonem prawem na WKM przyszła, nie podbiłeś nas mocą, ani mieczem swobodnymi ludźmi będąc, nie będąc tego powinni, jeno z nadziei tej, któreśmy o WKMci jeszcze w dzieciństwie WKMci wybralichmy cię sobie za Pana nie inszym sposobem, jedno, iżbyś wolnym ludziom panował a nie inaczej, jeno wedle prawa, a swobód naszych, a chociaż królowie polscy tak swobodnym ludziom rozkazywali, sławnie przedsię panowali”, Dyaryusz sejmu piotrkowskiego 1548, w: Dyaryusze sejmów koronnych 1548, 1553 i 1570 r., wyd. J. Szujski, Kraków 1872, s. 221-222. Bardzo podobne sformułowania na sejmach 1553 i 1563 r. odnototowane w: Dyaryusz sejmu krakowskiego r. 1553, w: ibidem, s. 1; Źrzódtopisma do dziejów Unii Korony Polskiej i W. Księstwa Litewskiego, wyd. A. T. Działyński, Poznań 1856, s. 6.

34 H.-J. Bömelburg, Polska myśl historyczna a humanistyczna historia narodowa (1500-1700), tł. Z. Owczarek, wprow. A. Lawaty, Kraków 2011, s. 281, 172-173; M. Wyszomirska, Rokosz Gliniański i „Rady Kallimacha” a doktryna ztotej wolności, w: Nad spoteczeństwem staropolskim, t. 1, wyd. W. Walczak, K. Łopatecki, Białystok 2007, s. 73-82; A. Prochaska, Rokosz lwowski w r. 1537, „Kwartalnik Historyczny”, 16, 1902, s. 1-22, 208-242, 381-400.

35 W. Zakrzewski, Po ucieczce Henryka. Dzieje bezkrólewia 1574-1575, Kraków 1878.

36 Por.: K. Lepszy, Rzeczpospolita Polska w dobie sejmu inkwizycyjnego (1589-1592), Kraków 1939; J. Maciszewski, Wojna domowa w Polsce (1606-1609), t. 1, Warszawa 1969. Ostatnio na temat rokoszu: E. Opaliński, Zjazd rokoszowy warszawski w październiku 1607 r., „Kwartalnik Historyczny”, 121, 2014, s. 521-539.

37 Por. H. Wisner, Wypowiedzenie postuszeństwa czy detronizacja Zygmunta III?, „Czasopismo Prawno-Historyczne”, 39, 1987, s. 173-185. 
zdecydowano o rozpoczęciu procedury prawnej, powołano się na wcześniejsze, wielokrotne i bezskuteczne, upomnienia. Stanisław Stadnicki, gorący zwolennik detronizacji Zygmunta III, miał powiedzieć pod Lublinem, na zjeździe otwierającym rokosz w 1606 r.: „Mówicie posłać, napomnieć króla. Osiemnaście lat napominamy go, a nie dba nic; jak ten Artykuł zowią, którego nie poruszył?”. Jak dodawał, praktyka upominania króla nie przyniosła skutku, dotąd bowiem król „wymilczał się ze wszystkiego"38.

Podkreślając legalizm szlachecki i szacunek dla instytucji monarchii, łatwo ulec pokusie rozciągnięcia tych poglądów - znanych z wystąpień sejmowych czy publicystyki - na całość narodu politycznego. Wbrew zapewnieniom o wierności i przywiązaniu do prawa w Polsce dochodziło do zamachów na królów. Tajemnicą owiany jest zamach na Zygmunta I w roku $1523^{39}$. Na sejmie 1569 r. Zygmunt August miał podobno zażądać zmiany przywileju mielnickiego, motywując to obawą o życie: „Bądź długo bądź krótko musicie tego statutu de crimine Maiestatis poprawić, chcecie podobno, aby mi puginał albo kulkę w bok kto wsadził" 40 . Na tym the najsłynniejszy - dlatego że zrealizowany - wydaje się być zamach Michała Piekarskiego, który w 1621 r. ugodził czekanem Zygmunta III ${ }^{41}$.

Podsumowując te krótkie wyliczenia, trzeba podkreślić słuszność założeń i tezy Schorn-Schütte o wspólnocie tradycji politycznej znajdującej wyraz w dyskusji wokół granic władzy świeckiej. W Rzeczypospolitej argumentację teologiczną bardzo rzadko wykorzystywano jednak przeciw monarsze ${ }^{42}$. Nie wynikało to z niewiedzy o sytuacji w Europie Zachodniej i nieznajomości toczonych tam sporów, lecz ze specyfiki kultury politycznej w Polsce XVI stulecia. Złożoność tej recepcji można krótko pokazać na przykładzie Interim augsburskiego.

Interim dotyczyło także władzy Jagiellonów, cesarz usiłował bowiem skłonić władcę Prus Książęcych do akceptacji dokumentu, a sam Albrecht uważał się za obrońcę nauki Marcina Lutra. Odpisy dokumentów związanych z Interim zostały natychmiast przesłane do Krakowa, a następnie do Królewca, gdzie wyrażano obawy, że dowodzą one upadku reformacji ${ }^{43}$. Biskup

38 Diariusz „Zjazdu pod Lublinem”, BCz, rkps 343, s. 131-161 [=BN, Mf 11670], s. 152 („O toż tak Ja, Stanisław Stadnicki z Łańcuta, Króla Zygmunta III nie mam za Pana i nie przyznawam, bo mi prawo złamał i wolę umrzeć, niż go za Pana mieć”).

39 Zob. Z. Wojciechowski, Zygmunt Stary (1506-1548), Warszawa 1979, s. 190, przyp. 23.

40 Dyaryusze sejmowe r. 1585, wyd. A. Czuczyński, Kraków 1901, s. 185-186.

41 U. Augustyniak, Wazowie i „królowie rodacy”. Studium wtadzy królewskiej w Rzeczypospolitej XVII wieku, Warszawa 1999, s. 118.

42 Por. eadem, Wstęp, w: Państwo świeckie czy księże? Spór o rolę duchowieństwa katolickiego w Rzeczypospolitej w czasach Zygmunta III Wazy. Wybór tekstów, wyd. U. Augustyniak, Warszawa 2013, s. 103-104.

43 Zob.: Elementa ad fontium editiones, t. 38, ed. C. Lanckorońska, Romae 1960 -1992, nr 1163, s. 119-122: K. Konarski do Albrechta, Kraków, 25 IV 1549 
Augsburga, kardynał Otto Truchseß, postawił Albrechtowi ultimatum: tylko przyjmując kompromis cesarski, uzyska zgodę cesarza na małżeństwo z Jagiellonką, o które wówczas zabiegał. Książę Prus i jego agenci przypuszczali, że odpowiedzialność za tę nieprzychylną odpowiedź ponoszą biskup Samuel Maciejowski lub królowa Bona ${ }^{44}$.

$\mathrm{Na}$ spotkanie z Albrechtem do Prus przybył wówczas (w czerwcu 1549 r.) Jan Łaski, przebywający od kilku lat na emigracji najwybitniejszy polski teo$\log$ protestancki ${ }^{45}$. Wedle Oskara Bartla Łaski zabiegał wówczas nie tylko o zgodę króla i królowej na powrót do Polski, lecz uczestniczył także w rozmowach na temat ewentualnego nowego sojuszu protestanckiego wymierzonego w Habsburgów ${ }^{46}$. Po spotkaniu z księciem Łaski został wezwany do powrotu do Emden we Fryzji Wschodniej, gdzie przygotowano wówczas wersję Interim, którą winni zaakceptować duchowni pracujący w księstwie. Wielu duchownych, na czele z superintendentem Łaskim, odrzuciło dokument. Sprzeciwili się ustanowieniu kapłanów mających celebrować msze oraz nakazowi przywdziewania lnianych komż podczas rozdzielania eucharystii, sprawowania chrztów i głoszenia kazań. W wyniku sporu przed przeciwnikami Interim zamknięto kościoły, zaczęli więc wygłaszać kazania w szkołach i na cmentarzach ${ }^{47}$. Eskalacja konfliktu zmusiła Łaskiego do opuszczenia księstwa i udania się w październiku 1549 r. do Bremy, a następnie do Hamburga. Wywołana przez Interim tułaczka Łaskiego zakończyła się w maju 1550 r., gdy przybył do Anglii ${ }^{48}$.

W otoczeniu dworu królewskiego znano sytuację w Rzeszy po uchwaleniu Interim z bezpośrednich relacji Stanisława Hozjusza i Andrzeja Frycza Modrzewskiego, którzy w 1549 r. odbyli podróż dyplomatyczną do Wiednia, Antwerpii i Brukseli ${ }^{49}$. Kanclerz Samuel Maciejowski prosił Hozju-

(przesyła Albrechtowi odpis); ibidem, nr 1164, s. 122-124: S. Bojanowski do Albrechta, Kraków, 29 IV 1549.

44 Por.: ibidem, nr 1195, s. 166-167: S. Bojanowski do Albrechta, Kraków, 14 IX 1549 („Item offensam esse Suam Ilustrissimam Dominacionem Augustani et nostri Cracoviensis Episcopis practica, qui Suae Ill. Dominacioni sororem Regis certo promittebant, si Interim recipiat"); Elementa, t. 43, nr 78, s. 79-80 (G. Tarło do Albrechta, Piotrków, 30 XI 1548).

45 Zob. H. Jürgens, Johannes a Lasco in Ostfriesland: der Werdegang eines europäischen Reformators, Tübingen 2002, s. 334-335.

46 O. Bartel, Jan Easki, Warszawa 1999, s. 163; zob. też: Joannis a Lasco Opera tam edita quam inedita, t. 2, ed. A. Kuyper, Amstelodami 1866, nr 58, s. 628 : J. Łaski do Hardenberga, Gdańsk, 1 VIII 1549.

47 Obszerny opis w: Elementa, t. 38, nr 1196 [=Kuyper, Opera, t. 2, nr 59, s. 628-632]: J. Łaski do Albrechta, Emden, 18 IX 1549; omówienie w: O. Bartel, op. cit., s. 164-165; H. Jürgens, op. cit., s. 340-341.

48 O. Bartel, op. cit., s. 165-166; H. Jürgens, op. cit., s. 340-344.

49 Na temat misji: A. Sucheni-Grabowska, Stanistaw Hozjusz jako dyplomata Zygmunta Augusta. Wokót Traktatu Praskiego z 1549 roku, „Studia Warmińskie”, 
sza w kwietniu 1549 r., aby przysłał mu dokumenty, o których rozmawiali przed jego wyjazdem, zwłaszcza zaś konstytucje przyjęte w Augsburgu ${ }^{50}$. Do celów politycznych dworu młodego Jagiellona nie należało jednak wspieranie stronnictwa antycesarskiego, lecz przeciwnie - szukanie u Habsburgów poparcia w zmaganiach z opozycją w Polsce. W słynnym liście z 18 czerwca Zygmunt August zalecał Hozjuszowi odbyć prywatną rozmowę z Ferdynandem i wyrazić żal z powodu dawnych nieporozumien ${ }^{51}$. Władca prosił Ferdynanda o radę, skarżąc się na opozycję w kraju i dodając, że chciał (bezowocnie) ten opór przezwyciężyć łagodnością, a nie surowością ${ }^{52} .2$ lipca 1549 r. podpisano przymierze między Ferdynandem i Zygmuntem Augustem, zawierające ustęp o pomocy przeciw buntownikom ${ }^{53}$.

Wkrótce wysłano na dwór Ferdynanda dodatkowo prepozyta gnieźnieńskiego Andrzeja Czarnkowskiego ${ }^{54}$. W instrukcji polecono posłowi, aby w imieniu Zygmunta Augusta zaofiarował pomoc w podjęciu obrad soboru trydenckiego, przedstawił propozycję spotkania obu monarchów oraz zaprosił poselstwo Ferdynanda do udziału w zbliżającym się sejmie ${ }^{55}$. Czarnkowski przekonywał Ferdynanda, że opór przeciw Zygmuntowi Augustowi jest dziełem niewielkiej grupy skupionej w Wielkopolsce wokół Andrzeja Górki.

18, 1981, s. 99-156, tu s. 142-143; Z. Wurst, Legacya Stanistawa Hozyusza cesarza Karola Vi króla Ferdynanda I w roku 1549, „Przewodnik Naukowy i Literacki”, 31, 1903, tu s. 193-194.

50 „Libros, de quibus locutus sum cum Dne. V. R., mitti mihi velim, praesertim constitutiones Augustani conventus", S. Maciejowski do Hozjusza, Kraków, 29 IV 1549, w: Stanislai Hosii [- - Epistolae, t. 1, wyd. F. Hipler, Cracoviae 1879, nr 322, s. 302-303.

51 Por. Zygmunt August do Hozjusza, Kraków, 18 VI 1549, w: ibidem, nr 344, s. 329-331.

52 „Quorum nos voluntates ferendo aliquantisper emollire studemus: neque enim a severitate et asperitate auspicari regnum nobis est in animo, sed lenitate et clementia maiorum nostrorum instituto animos nostrorum hominum adiungere nobis cupimus. Verum si forte minime victi patientia et facilitate nostra, molesti porro nobis esse pergerent ac de omnibus seu de dignitate etiam nostra detrahere conarentur, quid tunc nobis faciendum esse censeat Mtas. eius?", ibidem; list omówił Z. Wurst (idem, op. cit., s. 391).

53 AGAD, dok. pergaminowe, nr 5425; Haus- Hoff- und Staatsarchiv (Wiedeń) [dalej: HHStA], Polonica I, Karton 6, fasc. 1, k. 43rec.-62rec., 64rec.-70rec.; druk w: Codex Diplomaticus Regni Poloniae et Magni Ducatus Lituaniae, t. 1, wyd. M. Dogiel, Vilnae 1759, s. 213-219; zob. A. Sucheni-Grabowska, op. cit., s. 79 , przyp. 1.

${ }^{54}$ HHStA, Polen I, Karton 6, fasc. 1, k. 93: Zygmunt August do Ferdynanda, Kraków, 3 XII 1549; ibidem, k. 104: S. Maciejowski do Ferdynanda, Kraków, 4 XII 1549. Wzmianka w: Elementa, t. 38, nr 1215, s. 188-189: A. Cikowski do Albrechta, Kraków, 11 XII 1549. Z. Wurst (zob. idem, op. cit., s. 676) błędnie nazywa go Adamem.

55 HHStA, Polonica I, Kasten 6, fasc. 1, k. 107-108: „Instructio”, Kraków, 6 XII 1549. 
Starosta Wielkopolski miał wsparcie arcybiskupa Mikołaja Dzierzgowskiego oraz marszałka wielkiego koronnego Piotra Kmity, a także elektora Brandenburgii ${ }^{56}$. Odpowiedź Ferdynanda była bardzo przychylna. Król rzymski, dostatecznie poinformowany o starciach Zygmunta Augusta z opozycją na sejmie piotrkowskim, ubolewał nad faktem pojawienia się buntowników i spisków przeciw monarsze ${ }^{57}$. Mimo to zachęcał króla Polski do łagodności i unikania za wszelką cenę bratobójczych walk, przelewania krwi chrześcijańskiej i wystąpienia przeciw poddanym, prowadzącego tylko do osłabienia i wyludnienia kraju ${ }^{58}$. Zamiast tego Ferdynand radził Zygmuntowi Augustowi pozbawić urzędów i godności opierających się królowi członków elity politycznej. Ostrzegał także przed tym, by owa zaraza, która opanowała już Wielkopolskę, nie rozprzestrzeniła się w Małopolsce.

Po powrocie do Polski Hozjusz zdał relację z poselstwa na sejmie piotrkowskim 23 czerwca 1550 r. ${ }^{59}$ Drogi obu humanistów - Frycza i Hozjusza - szybko się rozeszły, choć obaj przywoływali Interim augsburskie w swoich dziełach. Frycz mimo zbliżenia się do obozu protestanckiego powoływał się na Interim w dziele $O$ poprawie Rzeczypospolitej, uważając projekt augsburski za realną próbę kompromisowego rozwiązania konfliktu konfesyjnego. W rozdziałach księgi $O$ kościele poświęconych pokucie cytował tekst Interim oraz fragmenty polemik Filipa Melanchtona i Jana Kalwina ${ }^{60}$. Co ciekawe, do opinii Melanchtona na temat Interim nawiązał wkrótce także Marcin Kromer, polemizując z konfesją przedstawioną przez posłów na sejmie roku $1555^{61}$. Kilkanaście lat później przeciwnik Frycza, Hozjusz ponownie sięgnął po przykład Interim w piśmie poświęconym - nagannej

56 Niesygnowany i niedatowany tekst legacji w: HHStA, Polonica I, Karton 6, fasc. 1, k. 140-149; zob. Z. Wurst, op. cit., s. 677-679.

57 HHStA, Polonica I, Karton 6, k. 128-133, 135-140: „Responsum pro Ser. Regis Oratore” („esse videlicet nonnullos, qui contra Ser.tem. eius tumultus et seditiones excitare, ac alios in factionem suam protrahere, adeoq. publicam Regni quietem et tranquillitatem turbare non cessent").

58 Por.: „cum primis autem Ser.ti eius consulit a bello, quod non contra externos hostes, sed intra viscera Regni futurum esset, quod fieri queat, magnopere cavendum esse", ibidem.

59 Zob. Stanislai Hosii [- - Epistolae, t. 1, nr 376-377, s. 372-392.

60 Por.: „Etsi illa satisfactio, quae culpam et aeternam poenam expiat, soli Christo tribuenda est, satisfactio tamen, quae in poenitentiae fructibus constistit [! - winno być: consistit], maxime autem in ieiunio, eleemosyna et oratione siue a nobis suscepta, siue a parochis et dispensatoribus sacramentorum iniuncta, si ex fide et charitate peragitur, peccatorum causas excindit et peccati reliquiis medetur ac temporalem poenam uel tollit, uel mitigat et in exemplum denique adhibetur", Andreae Fricii Modrevii Commentariorum de republica emendanda: libri quinque, wyd. K. Kumaniecki, Warszawa 1953, s. 133, s. 356; ten fragment w: Das Augsburger Interim, s. 85.

61 Por. L. Finkel, Konfesya podana przez postów na sejmie piotrkowskim w r. 1555, „Kwartalnik Historyczny”, 10, 1896, s. 276-285, tu s. 270. 
w jego oczach - lekturze Biblii przez osoby świeckie. Hozjusz uważał, że Interim, przywracając część ceremonii katolickich, pozwalało luteranom pozostać $\mathrm{w}$ tajemnicy przy ich konfesji: „ci, którzy przyjęli Interim potym byli Luteranowie jako i przedtym, jeno iż nie kędy mięsa nie jedzą w poście, a w piątek, a kiedy mszą swoję niepobożną sprawują, kapłańskich ubiorów używają na niektórych miejscach" ${ }^{2}$. Paradoksalnie więc to pisarz zbliżony do obozu protestantów i bliski współpracownik Jana Łaskiego wyrażał się pochlebnie o dokumencie cesarskim, podczas gdy katolik i zażarty wróg protestantyzmu krytykował Interim za zbytnią ustępliwość.

Interim było zatem dobrze znane w Polsce, lecz nigdy nie wywołało takiej reakcji protestantów, która nawet w niewielkim stopniu przypominałaby żywą polemikę prowadzoną w Europie Zachodniej. Wręcz przeciwnie, wiele środowisk przywitało dokument cesarski jako propozycję kompromisową, umożliwiającą zbliżenie katolików i protestantów. Wydaje się, że stanowi to kolejny dowód na opóźnienie w kształtowaniu się świadomości konfesyjnej polskich protestantów, gdyż Interim nie stanowiło dla nich bezpośredniego zagrożenia. Wyraźne cechy konfesyjne kościoły protestanckie w Polsce zyskały dopiero w drugiej połowie wieku XVI.

Fakt, że w dyskusji na temat granic władzy w Koronie rzadko sięgano po język teologii, nie podważa jednak głównego argumentu na temat uniwersalnego charakteru języka politycznego i politycznych argumentów. W Koronie również można wskazać przykłady posługiwania się figurą trzech stanów bądź to w artystotelesowsko-scholastycznym duchu, bądź w łonie aktualnych dyskusji na temat stanowych powinności społecznych. W tradycji komentarzy do pism Arystotelesa do początku XVII w. i Przydatków Sebastiana Petrycego z Pilzna występował schemat ethica - economia - politica, odpowiadający głównym gałęziom filozofii, a zarazem przestrzeniom życia społecznego. W drukowanej literaturze popularnej motyw trzech stanów pojawił się w momencie jej narodzin w Rejowej Krótkiej rozprawie między Panem, Wójtem a Plebanem, mającej reformacyjny charakter nie tylko ze względu na dość zjadliwą krytykę kleru, lecz także przez przywołanie kategorii „prawej wiary", gwarantującej zbawienie niezależnie od uczynków ${ }^{63}$. W literaturze publicystycznej i polemicznej drugiej połowy XVI w. podobne rozróżnienie pojawiło się w traktacie Andrzeja Wolana $O$ wolności szlacheckiej, który dzielił społeczeństwo na trzy stany: szlachciców, mieszczan i oraczy („nobiles, oppidiani, aut agricolae") ${ }^{64}$. Tym gestem Wolan wykluczył z ziemskiej społeczności instytucję Kościoła.

62 Zob. S. Hozjusz, Księgi o jasnym a szczyrym stowie bożym, wyd. M. Korolko, Kraków 1998, s. 116-117.

63 Por. J. T. Maciuszko, Mikotaj Rej. Zapomniany teolog ewangelicki z XVI w., Warszawa 2002, s. 59-79.

${ }^{64}$ A. Wolan, De libertate politica sive civili, wyd. M. Eder, R. Mazurkiewicz, Warszawa 2010, s. 104-106. 
Odwołania i nawiązania do koncepcji trzech stanów społecznych można odnaleźć nie tylko w manifeście Okszyca, lecz także w rękopiśmiennej korespondencji katolickich polemistów. Wkrótce po śmierci Piotra Tomickiego biskup Jan Latalski w liście do Zygmunta zauważył, że biskup krakowski za życia położył wielkie zasługi dla króla i „republiki królestwa zarówno świeckiego, jak i kościelnego" ${ }^{65}$. Jak przypuszczają wydawcy korespondencji Hozjusza, wyrażenie „respublica ecclesiastica Regni” mogło pochodzić spod pióra przyszłego biskupa warmińskiego, który wówczas przebywał na dworze Latalskiego. W późniejszej korespondencji biskupów i kanoników odnajdujemy podobne odwołania do koncepcji „respublica ecclesiastica”, ukutej w celu obrony praw Kościoła ${ }^{66}$. Wydaje się, że pod piórem katolickich polemistów określenia „status ecclesiasticus” czy „respublica ecclesiastica" nabierały politycznego znaczenia jako argument na rzecz obrony pozycji Kościoła katolickiego, jednego ze stanów społecznych. Co więcej, to właśnie w korespondencji Hozjusza można odnaleźć kategoryczne sformułowanie „oportet Deo magis oboedire quam hominibus” (Dz 5, 29) ${ }^{67}$. Biskup warmiński posługiwał się nim w stosunku do króla, nie chcąc zgodzić się na ustępowanie wobec żądań protestantów w Chełmnie i Elblągu. Także fragment Księgi Samuela pojawiał się u katolickich hierarchów i korespondentów Hozjusza, wzywających świeckich do wierności Kościołowi rzymskiemu i tradycyjnej wierze ${ }^{68}$. Katolicki hierarcha powoływał się na nowo- i starote-

65 Por.: „Non longe abierit Sacra Mtas. V. Antecessor meus Petrus Tomicius, vir et de Sacra Mte. V. et de Republica tam profana quam ecclesiastica Regni huius optime meritus, in cuius ego locum beneficio Sacrae Mtis. V. successi”, J. Latalski do Zygmunta, Kraków, październik 1536, w: Stanislai Hosii [- -] Epistolae, t. 1 , nr 21, s. 40-42.

66 Zob. Stanislai Hosii [- - Epistolae, t. 2, cz. 2, nr 1663: S. Hozjusz do S. Karnkowskiego, Lidzbark Warmiński, 19 IX 1556 („Petunt enim, ut iura unius ordinis, ecclesiastici nimirum, labefactet, quae se conservaturam aeque iuraverit atque iura alterius ordinis. Quod si libere volunt Mti suae, ut una in re violet iusiurandum suum, eadem opera licitum illi fore, ut etiam illud, quod ordini saeculari praestitit iusiurandum violet").

67 Zob. ibidem, nr 1613, s. 717-718: S. Hozjusz do S. Karnkowskiego, Lidzbark Warmiński, 4 VI 1556 („Nam si datum fuerit mandatum tale, respondebo vobis breviter: Oportet oboedire Deo magis quam hominibus; sin autem absoluta potestate uti volueritis, quid aliud ex eo colligam quam quod me Episcopum esse non vultis"); ibidem, nr 1838: S. Hozjusz do Zygmunta Augusta, Lidzbark Warmiński, 3 X 1557 („Ubi autem Dei causa agitur, non mihi licet aliud dicere, quam quod illi dixerunt: "oportet oboedire magis Deo quam hominibs"”); ibidem, nr 1960, s. 902-903: S. Hozjusz do M. Dzierzgowskiego, Lidzbark Warmiński, 19 X 1557 („Accepi autem litteras Regiae Mtis. ipsius manu subscriptas, quibus postulat, ut eum loco ne moveam. Ego vero Mti. eius respondi, quod oportet magis oboedire Deo quam hominibus; simul petivi, ne quid eiusmodi imperat mihi Mtas. eius, quae mihi catholico Episcopo facere non licet").

68 Zob. ibidem, nr 1296, s. 473: P. Głogowski do S. Hozjusza, Pułtusk, 26 XI 
stamentowe formuły, tradycyjnie wykorzystywane w sporach władzy kościelnej ze świecką. Zygmunt August, będący obiektem tych nieraz histerycznych ataków i deklaracji Hozjusza, ze zrozumieniem pisał, że biskup czyni tylko swoją powinność („officium”) ${ }^{69}$.

Podsumowując powyższe rozważania, trzeba jeszcze raz pokreślić słuszność tezy bronionej przez Schorn-Schütte: w nowożytności istniał ogólnoeuropejski język polityki bazujący na wspólnej edukacji akademickiej, podzielanym systemie wartości i ogólnie znanym systemie odniesień, metafor i figur. W Polsce i w Rzeczypospolitej kanonizacja prawa do oporu na przełomie średniowiecza i nowożytności, a następnie uchwalenie w $1573 \mathrm{r}$. gwarancji wyznaniowych połączonych z formułą wypowiedzenia posłuszeństwa sprawiły, że protestanci, broniąc swojej pozycji, wykorzystywali tradycyjną formę samoobrony i powoływali się na wolności i przywileje. $Z$ tego punktu widzenia nowożytna Europa - we własnych oczach - nie znała właściwie buntowników: wszyscy strzegli jedynie własnych praw, wolności i przywilejów ${ }^{70}$.

Nawet jednak ten prawniczy język wolności był głęboko zanurzony w religii, tak, że dyskursów polityki i wyznania nie można od siebie oddzielić. Na określenie tego specyficznego języka Schorn-Schütte posługuje się terminem „teologii politycznej”, zapożyczonym od Carla Schmitta. Wedle efektownego ujęcia Schmitta „wszystkie istotne pojęcia z zakresu współczesnej nauki o państwie to zsekularyzowane pojęcia teologiczne" 71 . Podczas

1554 (powołanie na 1 Sam 15, 28 jako konkluzja długiego wywodu: „Ceterum qua diligentia quantove studio a maioribus nostris erat prospectum, ne unitas fidei apud nos scinderetur, annales nostros atque statua, quae quottidie manibus suis terunt, videant. Certe hac ipsa maiorum nostrorum diligentia effectum est, ut apud nos Christianae religionis integritas nullo hactenus novitatis nidore esset infecta et depositum hoc ita ab illis conservatum, ut incorruptum omnino ad nostra usque tempora transmiserint").

${ }^{69}$ Zob. ibidem, t. 2, cz. 1, nr 1319, s. 487: Zygmunt August do S. Hozjusza, Rudniki, 10 I 1555 („Facit Ptas. V. officium suum, quae nos de rebus iis admonet, quae ad retinendam veterem religionem tranquillitatemque terrerum nostrarum Prussiae pertinere putat").

70 Por. L. Schorn-Schütte, Kommunikation über Herrschaft. Obrigkeitskritik im 16. Jahrhundert, w: eadem, Perspectum, s. 299-342; R. v. Friedeburg, In Defense of Patria. Resisting Magistrates and the Duties of Patriots in the Empire from the 1530s to the 1640s, „Sixteenth Century Journal”, 32, 2001, s. 357-382.

${ }^{71}$ Zob. C. Schmitt, Teologia polityczna i inne pisma, tt. i wstęp. M. A. Cichocki, wyd. 2 poszerz., Warszawa 2012, s. 45-104. Na temat Schmittowskiego pojęcia "teologii politycznej” zob. J. Manemann, Carl Schmitt und die Politische Theologie. Politischer Anti-Monotheismus, Münster 2002, s. 87-201, tu np. s. 99 („Schmitts politische Theologie, die gewissermaßen als Frühreaktion auf die in der Zeit nach dem Ersten Weltkrieg sich ausbildende reflexive Modernisierung zu verstehen ist, bietet nun in diesen Gemengelagen sozialer Desorganisation 
gdy Schmittowskie określenie opisuje przede wszystkim genezę nowoczesnego rozumienia polityki i postuluje analogię prawa i teologii, Schorn-Schütte próbuje uchwycić specyfikę języka politycznego epoki nowożytnej. Z perspektywy historyka filozofii dzieje tak rozumianej „teologii politycznej” przedstawił ostatnio Merio Scatolla, definiując ją jako „rozumowy dyskurs o wspólnym życiu ludzi" ${ }^{72}$. Redukowanie głównych procesów w epoce nowożytnej do powstania absolutnego państwa, sekularyzacji i rozdzielenia sfer religii oraz polityki czy doszukiwanie się zaczątków nowoczesności i „niewidzialnej istotowości”, która miałaby się dopiero objawić, wykrzywia obraz epoki. Schorn-Schütte oddaje nowożytności sprawiedliwość, ukazując ją jako czas nieustannych starć i wyznaczania granic.

Dr Maciej Ptaszyński, adiunkt w Instytucie Historycznym Uniwersytetu Warszawskiego. Prowadzi badania nad dziejami reformacji polskiej, a szczególnie jej związków z reformacją europejską i jej koryfeuszami oraz późnym humanizmem w Rzeczypospolitej. E-mail: m.ptaszynski@uw.edu.pl.

und des Zerfalls von Traditionen eine Verhaltenslehre, die durch radikale Unterscheidungen Vertrautszonen herzustellen und Identitäten zu bestimmen versucht").

${ }^{72}$ M. Scattola, Teologia polityczna, tł. P. Borkowski, Warszawa 2011, s. 11. 